\title{
Effectiveness of Some Organic Fertilizers and Bio-Control Agents for Controlling Root-Knot Nematodes Meloidogyne spp. in Cowpea Forage (Vigna unguiculata) in New Valley, Egypt.
}

Abdel-Monaim M.F.; Sahar Abdel-Bast H. and Rania Wahdan $\mathbf{H}$.

Plant Pathol. Res. Inst., Agric. Res. Centre, Giza, Egypt

\begin{abstract}
$\mathbf{T}$
he effect of some organic fertilizers viz., Farmyard manure, chicken manure, date palm compost, filter cake mud and the two bio-control agents Trichoderma viride and Bacillus megaterium alone and/or in a combination against root-knot nematodes Meloidogyne spp., infecting cowpea forage plants under field conditions was studied. The combined treatments showed more efficacy for controlling Meloidogyne spp., reproduction than individual treatments; the most effective treatment in reducing root galling was the combined treatments between $B$. megaterium or $T$. viride with date palm compost, followed by the combined treatment of $T$. viride with filter cake mud. While, the greatest decrease of the numbers egg-masses per root system, and number of eggs per egg-mass were detected by the combined treatment $B$. megaterium with date palm compost. However, the highest reduction in second stage juvenile $\mathrm{j}_{2}$ in the soil was the combined B. megaterium with chicken manure. The tested treatments increased growth parameters significantly in growing two seasons compared with control treatment. The greatest of plant height, number of branches per plant, and fresh weight were recorded by the combined treatment $B$. megaterium with chicken manure. The combined treatments increased the content of cowpea forage from minerals viz., nitrogen, phosphorus, potassium, and protein. The highest of nitrogen and protein content of cowpea forage was recorded with the combined treatment $B$. megaterium with filter cake mud. As well as, the combined treatment $B$. megaterium with chicken manure recorded the highest contents of potassium and phosphorus in forage cowpea. The second part of this study studied the effect of the above mentioned treatments on the defense-related enzymes and total phenol contents in cowpea forage plants infected with, M. incognita under greenhouse conditions. The combination between organic fertilizers and bio-agents increased activities of defense-related enzyme peroxidase (PO), polyphenol oxidase (PPO), phenylalanine ammonia lyase (PAL), pathogenesis related protein (chitinase and $\beta 1,3$ gluconase) and total phenol contents more than applied individually.
\end{abstract}

Keywords: Bio-agents, Cowpea, Defense-related enzymes and Total phenol contents, Meloidogyne spp. and Organic fertilizers.

Cowpea forage (Vigna unguiculata L. Walp) is regarded as an important food legume and an essential component of the crop system in the tropical and subtropical 
drier region. The worldwide cowpea cultivated area was estimated at 34594770 Feddans in 2000 (Singh et al., 2002). Cowpea is being cultivated in vast areas of Asia, and Africa because of its hardy nature to tolerate moderate drought. It can be successfully cultivated on soils with low organic matter and reduced fertility status (Iqbal, 2015). Due to its warm-loving nature, cowpea has the ability to provide green forage in midsummer, when other forages disappear. It was introduced to Egyptian agriculture as a promising double-purpose forage and seed crop, as a green canopy or as a dry seed in animal diets (Hamd Alla et al., 2014).

Root-knot nematodes, Meloidogyne spp., are a major problem in most parts of the world where cowpea is grown. (Iheukwumere et al., 1995). The three roots-knot nematode species; Meloidogyne incognita, M. arenaria as well as, $M$. javanica, are the most destructive on cowpea. Root-knot nematodes are estimated to cause losses ranging from $10 \%$ to $69 \%$ (Olowe, 2009). Symptoms of root-knot nematodes, Meloidogyne spp., damage includes the development of chlorosis of leaves, stunted growth, root galling, and excessive root branching (Adegbite, 2011).

Nematicides are generally recommended for nematode management; however, they are harmful to beneficial flora and fauna in the soil. Moreover, this environment is affected as a result of nematicides application (Fernandez et al., 2001). So it is essential to search for alternative control strategies for the management of root-knot nematodes, Meloidogyne spp. The addition of soil organic amendments to the soil is one of the alternative nematode management strategies. An organic amendment has beneficial effects on soil nutrition, soil physics, and soil biology and thus improves plant health and reducing the nematode population (Oka et al., 2000 \& Agyarko and Asante, 2005).

Biological control of plant-parasitic nematode is a more safety and inexpensive solution than the chemical control (Gowen and Ahmad, 1990). There are two main microbial groups that abound in soil, fungi, and bacteria. Some of them have great potential as bio-control agents for nematodes (Siddiqui and Mahmood, 1995). While, Sharon et al., 2001 mention that Trichoderma spp., are important biological control agents for the reduction of antibiotic and enzymatic hydrolysis root-knot nematode populations. Plant growth-promoting rhizobacteria (PGPR) are promising microorganisms for biological control of plant-parasitic nematodes. There are three bacterial mechanisms for reducing nematode infection: metabolite production that reduces egg hatching and causes juvenile death, the degradation of different root exudates that control nematode behavior and enhancing of plant defense mechanisms which lead to systemic resistance (Siddiqui et al., 2001). Bacillus megaterium and Trichoderma viride have recently been commonly used to promote plant growth and control plant-parasitic nematodes.

The objective of this study was to determine the effect of two bio-agents (T. viride) and plant growth promoting rhizobacteria (B. megaterium) singly or in combination with different organic soil amendments on;- (1)- the root-knot nematode Meloidogyne spp., reproduction of cowpea forage plants under field conditions. (2) - The effect of treatments on plant growth and yield components, (3) -Their effect on the content of cowpea forage from minerals viz., N, P, 
$\mathrm{K}$, and protein , and (4) -The relationships between the application of treatments and biochemical changes were assessed.

\section{Materials and Methods}

Source of cowpea forage seeds:

Cowpea forage (Vigna unguiculata L. Walp) Cultivar, Balady was obtained from the Legume Crop Research Department, Field Crop Research Institute, Agriculture Research Centre, Ministry of Agriculture, Giza, Egypt.

Source of bio-control agents:

Bacillus megaterium (BMM5 and Trichoderma viride (TVM2), were obtained from Dr. Montaser Fawzy Abdel-Monaim, Department of Plant Pathology, New Valley Research Station. The obtained bacterium was cultured in nutrient broth medium in $250 \mathrm{ml}$ flasks which were incubated at $25 \pm 2^{\circ} \mathrm{C}$ for $48 \mathrm{~h}$. A cell suspension of bacterium strain was adjusted to $2.5 \times 10^{8} \mathrm{CFU} / \mathrm{ml}$ (colony forming units). Trichoderma viride was cultured on potato dextrose agar (PDA) medium on Petri plates according to (Jansson et al., 1985). The fungus spore density was $1 \times 10^{6}$ spores/ $\mathrm{ml}$.

\section{Source of organic fertilizers:}

All of the organic fertilizers were obtained from New Valley Research Station, except the filter cake mud from Abu-Qurqas Sugar Factory.

\section{Field experiments:}

The experiment was conducted during the 2016 \& 2017 summer seasons at the New Valley Agriculture Research Station. The previous studies determined that field naturally infested with root-knot nematodes Meloidogyne spp. The experiments were divided into 45 plots, each plot $\left(3 \times 5 \mathrm{~m}^{2}\right)$, included 5 rows $(5 \mathrm{~m}$ in length and $60 \mathrm{~cm}$ width), and the initial population of nematodes were estimated for each plot. Five days before planting cowpea forage cv. (Balady) treatments were added in the two seasons as follows:-

1. B. megaterium (5 litres/fed.), 2. T. viride (5 liters/fed.), 3. Farmyard manure (5 ton/fed), 4. Chicken manure (2.5 ton/fed.), 5. Date palm compost (5 ton/fed.) 6. Filter cake mud (5 ton/fed.), 7. B. megaterium + farmyard manure, 8. B. megaterium + chicken manure, 9. B. megaterium + date palm compost, 10. B. megaterium + filter cake mud, 11. T. viride + farmyard manure, 12. T. viride + chicken manure, 13. T. viride + date palm compost, 14. T. viride + filter cake mud, 15. Check treatment (control) without treatment.

All plots were sown in hills $30 \mathrm{~cm}$ apart on one side, two seed per hill. All treatments were incorporated at planting row sites at the top of $20 \mathrm{~cm}$ of the soil surface. The experiment was conducted in a complete randomized block with three replicates for each treatment for two successive summer seasons (2016 \& 2017) using the same field design plots of applied treatments.

At 60 days after cultivation, a sample of twenty randomly plants from each experimental unit (plot) was taken and the following characteristics were recorded; plant length, number of branches. At the same time, a half of plot area was cutting to 
determine fresh forage yield (ton/fad.) then dry forage yield (ton/fed.) was determined. The other half of the experimental plot was left to maturity and the following measurements are estimated; No. of the seeds /pod, weight of 100 seeds and total seed yield $(\mathrm{Kg} / \mathrm{fed})$.

\section{Leaf mineral contents:}

Twenty-five mature leaves were collected randomly after 60 days of planting during season 2017. The samples of leaves were washed with tap water, rinsed twice in distilled water and air dried in an oven at $70^{\circ} \mathrm{C}$. The dried leaves were ground and digested by $\mathrm{H}_{2} \mathrm{O}_{2}$ and $\mathrm{H}_{2} \mathrm{SO}_{4}$ according to (Evenhuis and Dewaard, 1980). Suitable aliquots were taken for the determination of the mineral content. Nitrogen was determined by the Kjeldahl method (Anonymous, 1995). Phosphorus was determined according to (Murphy and Riley, 1962). Potassium was determined with a flame photometer. The concentrations of $\mathrm{N}, \mathrm{P}$, and $\mathrm{K}$ were expressed as percentages.

\section{Nematode parameters assessment:}

The egg masses have been stained by dipping the roots for $20 \mathrm{~min}$ in a solution of 0.015 percent Phloxine B (Daykin and Hussey, 1985) for three plants in each plot. Number of eggs per egg-mass was determined by selecting ten egg-masses randomly from each root system of three plants from each treatment, and shaking in $1 \%$ $\mathrm{NaOCI}$ solution for three min, the suspension of eggs was sieved through 200 and 500 mesh (Hussey and Barker, 1973). Released eggs were collected in $20 \mathrm{ml}$ water suspension on the sieve of 500 mesh, and the number of eggs was counted in $1 \mathrm{ml}$ by the aid of a light and counting slide $(10 \times)$. The average number of eggs/egg-mass was calculated. The number of root galls was counted and root gall index (G.I) was carried out according to (Taylor and Sasser 1978) where the scale of galling was $0=$ No galling; $1=1-10$ galls; $2=11-20 ; 3=21-30 ; 4=31-100$ galls and $5=$ more than 100 galls/ root. Two hundred and fifty g of soil from each plot was used to extract nematode, using sieving and Baermann pan technique (Barker et al., 1985). The extracted juveniles were counted by using $1 \mathrm{ml}$ counting slide under the stereoscopic microscope and the average number of second stage juveniles $\left(\mathrm{j}_{2}\right) / 250 \mathrm{~g}$ soil was calculated for each treatment. Finally, nematode reproduction factor (Rf) was calculated according to the formula $\mathrm{Rf}=\mathrm{Pf} \div \mathrm{Pi}$, where $\mathrm{Pf}$ is the final nematode populations, and $\mathrm{Pi}$ is the initial nematode populations (Oostenbrink, 1966).

Greenhouse experiments:

Effect of organic fertilizers and bio control agents on activity of defence-related enzymes in single and combined treatments under greenhouse conditions.

Nematode inoculum: Egg- masses of $M$. incognita, were picked up from pure culture pots of infected roots and placed in the sterilized plastic plates with sterile water and kept on the laboratory benches at room temperature $\left(23-25^{\circ} \mathrm{C}\right)$ and allowed to hatch for 3-5 days to use for experiments.

The second part of this study to determine the accumulation of peroxidase (PO), polyphenol oxidase (PPO), phenylalanine ammonia lyase (PAL), pathogenesis related protein (chitinase and $\beta 1,3$ gluconase) and total phenol contents during season 2017 was studied under greenhouse conditions. Cowpea forage cv. (Balady) 
seeds were planted in clay pots $30 \mathrm{~cm}$ in diameter (4 $\mathrm{kg}$ soil), filled with a sterilized mixture of clay and sand $(4: 1 \mathrm{w} / \mathrm{w})$. The organic fertilizers and bio-agents were added individually at 1 . B. megaterium (20 ml/pot.), 2. T. viride (20 ml/pot.), 3 . Farmyard manure (20 g/pot), 4. Chicken manure (10 g/pot.), 5. Date palm compost (20 g/pot.), 6. Filter cake mud (5 ton/fed.), and in combined as: 7. B. megaterium + farmyard manure, 8. B. megaterium + chicken manure, 9. B. megaterium + date palm compost, 10. B. megaterium + filter cake mud, 11. T. viride + farmyard manure, 12. T. viride + chicken manure, 13. T. viride + date palm compost, 14. T. viride + filter cake mud, 15. Check treatment (control). Each treatment was replicated 3 times. The pots were irrigated every three days. After germination, plants were thinned to one plant in each pot. Plants were inoculated with approximately 500 newly hatching second stage juveniles $\left(\mathrm{J}_{2}\right)$ of $M$. incognita per pot. Three untreated pots kept free to serve as a control. Ten days after nematode inoculation, one gram of plant root was homogenized in $10 \mathrm{ml}$ of ice-cold $50 \mathrm{mM}$ potassium phosphate buffer $(\mathrm{pH}$ 6.8) containing $1 \mathrm{M} \mathrm{NaCl}, 1 \%$ polyvinylpyrrolidone, (PVP), $1 \mathrm{~mm}$ EDTA and $10 \mathrm{~mm} \beta$ mercaptoethanol (Biles and Martyn, 1993). After filtration through cheesecloth, the homogenates were centrifuged at $8000 \mathrm{rpm}$ at $4^{\circ} \mathrm{C}$ for $25 \mathrm{~min}$. The supernatants (crude enzyme extract) were stored at $-20^{\circ} \mathrm{C}$ or immediately used for determination PO, PPO, PAL, chitanase and $\beta$-1,3-glucanase enzyme activities and total protein. In the case of individual enzyme under investigation, each treatment consisted of three replicates and three spectrophotometric readings using Milton Roy Spectrophotometer (Milton Roy spectronic1201) were taken per replicate. Then the extracts were used for assaying biochemical change associated with the tested treatments.

The activity of peroxidase enzyme was determined according to (Hammerschmidt et al., 1982). The activity of poly phenoloxidase enzyme was determined according to (Gauillard et al., 1993). The activity of Phenylalanine ammonia layse was assayed according to (Cavalcanti et al., 2007). The Chitinase activity was determined using the method described by (Wirth and Wolf 1992). Activity of $\beta$-1,3-glucanase enzyme was assayed according to (Pan et al., 1991).

Protein concentration:

The total protein content of the samples were quantified according to the described method (Bradford, 1976).

Determination of phenolic compounds:

The total phenol compounds (TPC) were assessed according to (Saikia et al., 2006).

Statistical analysis:

All experiments were performed twice. Analyses of variance were carried out using MSTAT-C program version 2.10 (Anonymous, 1991). Least significant difference (LSD) was employed to test for significant difference between treatments at $\mathrm{P} \leq 0.05$ (Gomez and Gomez, 1984). 


\section{R e s u l t s}

Effect of four organic fertilizers and two bio-agents on the cowpea forage (Balady) on root-knot nematode Meloidogyne spp., reproduction under field conditions:

The effect of organic fertilizers (farmyard manure, chicken manure, date palm compost, and filter cake mud) and bio-control agents ( $T$. viride) and (B. megaterium) in single and combined treatments were studied against root-knot nematodes Meloidogyne spp., reproduction. The results in Table 1 showed that all treatments reduced nematode infection significantly compared with control treatment under field conditions. The data also revealed that the combined treatments were more efficacious in controlling Meloidogyne spp., reproduction than individual treatment during season 2016. The most effective treatment in reducing root galling was the combined treatments $B$. megaterium or $T$. viride with date palm compost with (123) gall /root system, followed by the combined treatments $T$. viride with filter cake mud with a number of galls $(127.75) /$ root system. While the highest reduction of the number of eggs/egg-mass (162), and numbers of egg-masses/ root system (58.61) were detected by combining treatment $B$. megaterium with date palm compost. On the other hand, the highest reduction in second stage juvenile $\mathrm{j}_{2}$ was (120) $/ 250 \mathrm{~g}$ soil with the combined $B$. megaterium with chicken manure. While, during the season 2017, the results in Table 2 indicated that highest reduction in root galling was (152) / root system with combined $T$. viride and date palm compost.

The most effective treatments for reducing the number of eggs/egg-masses were the combination of date palm compost with B. megaterium (148), and T. viride (156). Combined treatments $B$. megaterium with chicken manure, and date palm compost gave the highest reduction of second stage juveniles $\left(\mathrm{j}_{2}\right) / 250 \mathrm{~g}$ soil with $(180)$. While, the gall index was (5) showed an evident susceptibility to nematode infection in the two seasons with all treatments. Consequently, the low reproduction factor (RF) showed that nematode multiplication was negatively affected, the combination of B. megaterium with chicken manure or date palm compost were more effective in reducing the final nematode population in two seasons 2016 and 2017. 
Table 1. Effect of four organic fertilizers alone and in combination with the two bio-agents on cowpea forage (Balady) on root-knot nematodes, Meloidogyne spp., reproduction during summer season 2016 under field conditions

\begin{tabular}{|c|c|c|c|c|c|c|}
\hline Treatment & 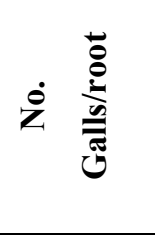 & & 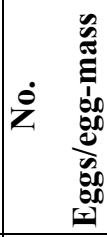 & 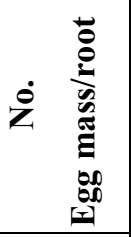 & 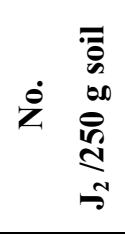 & $\begin{array}{l}\dot{x} \\
\stackrel{\dot{x}}{2}\end{array}$ \\
\hline B. megaterium & $175.50 \mathrm{~cd}$ & 5 & $189 \mathrm{~h}$ & $79.12 \mathrm{fg}$ & $240.00 \mathrm{f}$ & 0.48 \\
\hline T. viride & $179.25 \mathrm{bc}$ & 5 & $250 \mathrm{~d}$ & $120.27 \mathrm{c}$ & $300.50 \mathrm{c}$ & 0.60 \\
\hline Farmyard manure (A) & $192.00 \mathrm{~b}$ & 5 & $278 \mathrm{c}$ & $150.69 \mathrm{~b}$ & $328.50 \mathrm{~b}$ & 0.66 \\
\hline Chicken manure (B) & $172.50 \mathrm{~cd}$ & 5 & $229 \mathrm{e}$ & $112.88 \mathrm{~d}$ & $280.25 \mathrm{~d}$ & 0.56 \\
\hline Date palm compost $(C)$ & $170.00 \mathrm{~cd}$ & 5 & $200 \mathrm{~g}$ & $62.51 \mathrm{ij}$ & $220.5 \mathrm{~g}$ & 0.44 \\
\hline Filter cake mud(D) & $183.00 \mathrm{bc}$ & 5 & $288 b$ & $123.20 \mathrm{c}$ & $300.25 \mathrm{c}$ & 0.60 \\
\hline B. megaterium $+\mathbf{A}$ & $162.00 \mathrm{de}$ & 5 & $254 d$ & $96.36 \mathrm{e}$ & $280.25 \mathrm{~d}$ & 0.56 \\
\hline B. megaterium $+\mathrm{B}$ & $139.50 \mathrm{fg}$ & 5 & $177 \mathrm{i}$ & $65.41 \mathrm{i}$ & $120.25 \mathrm{i}$ & 0.24 \\
\hline B. megaterium $+\mathrm{C}$ & $123.00 \mathrm{~h}$ & 5 & $162 \mathrm{j}$ & $58.61 \mathrm{j}$ & $180.00 \mathrm{~h}$ & 0.36 \\
\hline B. megaterium $+\mathrm{D}$ & $135.00 \mathrm{fgh}$ & 5 & $234 \mathrm{e}$ & $75.44 \mathrm{gh}$ & $260.00 \mathrm{e}$ & 0.52 \\
\hline T. viride $+\mathrm{A}$ & $129.00 \mathrm{gh}$ & 5 & $214 f$ & $81.32 \mathrm{f}$ & $300.25 \mathrm{c}$ & 0.60 \\
\hline T. viride $+\mathrm{B}$ & $148.25 \mathrm{ef}$ & 5 & $200 \mathrm{~g}$ & $73.12 \mathrm{~h}$ & $320.00 \mathrm{~b}$ & 0.64 \\
\hline T. viride $+C$ & $123.00 \mathrm{~h}$ & 5 & $197 \mathrm{~g}$ & $66.10 \mathrm{i}$ & $280.50 \mathrm{~d}$ & 0.56 \\
\hline T. viride $+D$ & $127.75 \mathrm{gh}$ & 5 & $219 f$ & $76.03 \mathrm{fgh}$ & $280.00 \mathrm{~d}$ & 0.56 \\
\hline Control & $294.00 \mathrm{a}$ & 5 & $365 a$ & $212.36 \mathrm{a}$ & $720.5 \mathrm{a}$ & 1.4 \\
\hline
\end{tabular}

Different letters indicate significant differences among treatments within the same column according to least significant difference test $(\mathrm{P} \leq 0.05)$. 
Table 2. Effect of four organic fertilizers alone and in combination with the two bio-agents on cowpea forage (Balady) on root-knot nematodes, Meloidogyne spp., reproduction during summer season 2017 under field conditions

\begin{tabular}{|c|c|c|c|c|c|c|}
\hline Treatment & 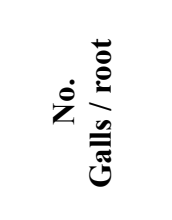 & 苞 & 乙. & 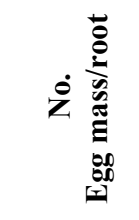 & 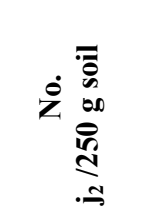 & $\underline{\simeq}$ \\
\hline B. megaterium & 171.50 bcde & 5 & $216 \mathrm{e}$ & $76.72 \mathrm{gh}$ & $240.50 \mathrm{~d}$ & 0.40 \\
\hline T. viride & $172.25 \mathrm{bcd}$ & 5 & $289 \mathrm{c}$ & $115.35 \mathrm{c}$ & $300.00 \mathrm{c}$ & 0.50 \\
\hline Farmyard manure $(A)$ & $177.50 \mathrm{~b}$ & 5 & $301 \mathrm{~b}$ & $140.33 \mathrm{~b}$ & $400.25 \mathrm{~b}$ & 0.66 \\
\hline Chicken manure (B) & $172.75 \mathrm{bcd}$ & 5 & $196 f$ & $112.00 \mathrm{~cd}$ & $400.75 \mathrm{~b}$ & 0.66 \\
\hline Date palm compost $(C)$ & $174.00 \mathrm{bc}$ & 5 & $187 \mathrm{~g}$ & $66.67 \mathrm{i}$ & 200.00 ef & 0.33 \\
\hline Filter cake mud(D) & $173.00 \mathrm{bcd}$ & 5 & $296 b$ & $105.33 \mathrm{~d}$ & $240.00 \mathrm{~d}$ & 0.40 \\
\hline B. megaterium $+\mathrm{A}$ & $167.50 \mathrm{cde}$ & 5 & $268 d$ & $94.67 \mathrm{e}$ & $220.50 \mathrm{de}$ & 0.36 \\
\hline B. megaterium $+\mathrm{B}$ & $165.00 \mathrm{def}$ & 5 & $165 \mathrm{~h}$ & $76.33 \mathrm{gh}$ & $180.00 \mathrm{f}$ & 0.30 \\
\hline B. megaterium $+\mathrm{C}$ & $154.00 \mathrm{~g}$ & 5 & $148 \mathrm{i}$ & $70.33 \mathrm{hi}$ & $180.00 \mathrm{f}$ & 0.30 \\
\hline B. megaterium +D & $163.25 \mathrm{ef}$ & 5 & $214 \mathrm{e}$ & $88.67 \mathrm{ef}$ & 200.25 ef & 0.33 \\
\hline T. viride $+\mathrm{A}$ & $166.25 \mathrm{cde}$ & 5 & $192 \mathrm{fg}$ & $81.67 \mathrm{fg}$ & $220.00 \mathrm{de}$ & 0.36 \\
\hline T. viride $+\mathbf{B}$ & $156.50 \mathrm{fg}$ & 5 & $188 \mathrm{~g}$ & $70.67 \mathrm{hi}$ & $240.00 \mathrm{~d}$ & 0.40 \\
\hline T. viride $+C$ & $152.00 \mathrm{~g}$ & 5 & $156 \mathrm{i}$ & $65.67 \mathrm{i}$ & 200.50 ef & 0.33 \\
\hline T. viride $+D$ & $164.50 \mathrm{def}$ & 5 & $211 \mathrm{e}$ & $80.00 \mathrm{~g}$ & $240.00 \mathrm{~d}$ & 0.40 \\
\hline Control & $288.00 \mathrm{a}$ & 5 & $379 a$ & $200.00 \mathrm{a}$ & $880.00 \mathrm{a}$ & 1.5 \\
\hline
\end{tabular}

Different letters indicate significant differences among treatments within the same column according to least significant difference test $(\mathrm{P} \leq 0.05)$.

The effect of four organic fertilizers alone and in combination with the two bioagents on plant growth and yield parameters of cowpea forage (Balady) infected with root-knot nematodes, Meloidogyne spp., under field conditions:

The results in Table 3 indicated that all the tested treatments significantly increased plant growth parameters compared to control treatment. In season 2016, combination of $T$. viride with chicken manure recorded the highest of plant height $(123.59 \mathrm{~cm})$. While, the number of branches was the highest (13) per plant with the combined $T$. viride with date palm compost, the applied treatment $B$. megaterium with chicken manure gave the highest of fresh and dry weight ton/feddan (14.56) and (3.45) respectively. The results of season 2017 showed that the highest of plant height was $(124.3 \mathrm{~cm})$ with chicken manure combined with $T$. viride. Date palm compost combined with $T$. viride gave the highest number of branches (12.84) per plant. The results in Table 4 revealed that the weight of 100 seed was the highest 
value $(9.43 \mathrm{~g})$ with combined treatment $B$. megaterium with farmyard manure. While, seed weight/Feddan was recorded the highest value $(1228.4 \mathrm{Kg})$ with combination of $T$. viride with date palm compost in season 2016. Also, chicken manure gave the highest number of seeds/ pod (11.83) in season 2016. While, the highest number of seeds/ pod (13.26) was recorded with the combined treatment B. megaterium with farmyard manure in season 2017. The applied treatment $T$. viride with date palm compos gave the highest seed weight /Feddan and gave approximately the same value in the both seasons (2016 and 2017)

Table 3. Effect of four organic fertilizers on plant growth and yield parameters of cowpea forage alone and in combination with fungal and bacterial bio-agents on root-knot nematodes, Meloidogyne spp., under field conditions during seasons 2016-2017

\begin{tabular}{|c|c|c|c|c|c|c|c|c|}
\hline \multirow[b]{2}{*}{ Treatment } & \multicolumn{4}{|c|}{ Summer season, 2016} & \multicolumn{4}{|c|}{ Summer season, 2017} \\
\hline & 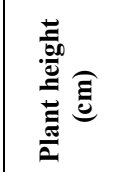 & 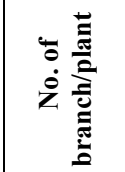 & 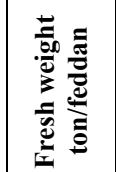 & 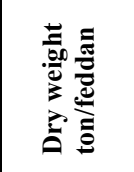 & 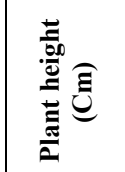 & 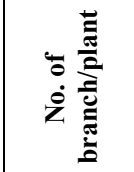 & 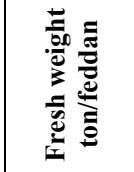 & 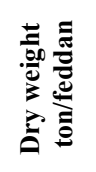 \\
\hline B. megaterium & $86.36 \mathrm{gh}$ & 8.67 ef & $10.26 \mathrm{cde}$ & 2.33 cdef & $85.03 \mathrm{hi}$ & $8.96 \mathrm{def}$ & 11.02 cde & $2.45 \mathrm{e}$ \\
\hline T. viride & $80.14 \mathrm{~h}$ & $7.33 \mathrm{fg}$ & 8.96 ef & $1.97 \mathrm{efg}$ & $83.25 \mathrm{i}$ & 7.86 efg & 9.32 ef & $2.09 \mathrm{f}$ \\
\hline $\begin{array}{l}\text { Farmyard manure } \\
\text { (A) }\end{array}$ & $90.25 \mathrm{fg}$ & $9.67 \mathrm{de}$ & $11.36 \mathrm{bcd}$ & 2.51 bcdef & $95.87 \mathrm{fg}$ & 10.24 bcde & $12.02 \mathrm{bcd}$ & $2.75 \mathrm{~cd}$ \\
\hline Chicken manure(B) & $99.36 \mathrm{ef}$ & $10.67 \mathrm{bcd}$ & $11.55 \mathrm{bc}$ & 2.61 bcdef & $102.60 \mathrm{def}$ & 10.89 abcd & 11.68 bcde & $2.59 \mathrm{de}$ \\
\hline $\begin{array}{l}\text { Date palm } \\
\text { compost(C) }\end{array}$ & $88.76 \mathrm{gh}$ & $7.67 \mathrm{fg}$ & $9.36 \mathrm{def}$ & $2.1 \mathrm{defg}$ & $93.65 \mathrm{hg}$ & 7.82 efg & $9.70 \mathrm{def}$ & $2.09 \mathrm{f}$ \\
\hline Filter cake mud(D) & $80.14 \mathrm{~h}$ & $6.33 \mathrm{~g}$ & $8.02 \mathrm{f}$ & $1.83 \mathrm{fg}$ & $82.47 \mathrm{i}$ & $7.02 \mathrm{fg}$ & $8.23 \mathrm{f}$ & $1.86 \mathrm{~g}$ \\
\hline B. megaterium $+\mathrm{A}$ & $105.36 \mathrm{cde}$ & $10.33 \mathrm{cde}$ & $12.69 \mathrm{ab}$ & 2.82 abcd & $110.50 \mathrm{bcd}$ & 10.24 bcde & $12.54 \mathrm{abc}$ & $2.76 \mathrm{~cd}$ \\
\hline B. megaterium $+\mathrm{B}$ & $112.36 \mathrm{bc}$ & $12.67 \mathrm{a}$ & $14.56 \mathrm{a}$ & $3.45 \mathrm{a}$ & $115.50 \mathrm{ab}$ & $12.47 \mathrm{ab}$ & $14.02 \mathrm{ab}$ & $3.11 \mathrm{~b}$ \\
\hline B. megaterium $+\mathrm{C}$ & $102.09 \mathrm{de}$ & $11.67 \mathrm{abc}$ & $11.89 \mathrm{bc}$ & 2.63 bcde & $106.40 \mathrm{cde}$ & $12.09 \mathrm{ab}$ & $12.34 \mathrm{abcd}$ & $2.72 \mathrm{~cd}$ \\
\hline B. megaterium $+\mathrm{D}$ & $95.68 \mathrm{efg}$ & $9.67 \mathrm{de}$ & $11.36 \mathrm{bcd}$ & 2.46 bcdef & $99.02 \mathrm{efg}$ & $9.36 \mathrm{cdef}$ & 11.56 bcde & $2.57 \mathrm{de}$ \\
\hline T. viride $+\mathrm{A}$ & $112.24 \mathrm{bc}$ & $12.33 \mathrm{ab}$ & $12.69 \mathrm{ab}$ & 2.82 abcd & $115.60 \mathrm{ab}$ & $12.63 \mathrm{ab}$ & $12.47 \mathrm{abc}$ & $2.73 \mathrm{~cd}$ \\
\hline T. viride $+\mathrm{B}$ & $123.59 \mathrm{a}$ & $12.00 \mathrm{abc}$ & $14.36 \mathrm{a}$ & $3.21 \mathrm{ab}$ & $124.30 \mathrm{a}$ & $11.58 \mathrm{abc}$ & $15.02 \mathrm{a}$ & $3.31 \mathrm{a}$ \\
\hline T. viride $+C$ & $115.48 \mathrm{ab}$ & $13.00 \mathrm{a}$ & $12.96 \mathrm{ab}$ & 2.9 abc & $112.70 \mathrm{bc}$ & $12.84 \mathrm{a}$ & $12.36 \mathrm{abcd}$ & $2.81 \mathrm{c}$ \\
\hline T. viride $+D$ & $110.24 \mathrm{bcd}$ & $10.67 \mathrm{bcd}$ & $11.36 \mathrm{bcd}$ & 2.56 bcdef & $108.80 \mathrm{bcd}$ & $10.47 \mathrm{abcd}$ & $11.02 \mathrm{cde}$ & $2.46 \mathrm{e}$ \\
\hline Control & $60.24 \mathrm{i}$ & $6.33 \mathrm{~g}$ & $5.96 \mathrm{~g}$ & $1.42 \mathrm{~g}$ & $63.60 \mathrm{j}$ & $6.06 \mathrm{~g}$ & $7.32 \mathrm{f}$ & $1.63 \mathrm{~h}$ \\
\hline
\end{tabular}

Different letters indicate significant differences among treatments within the same column according to least significant difference test $(\mathrm{P} \leq 0.05)$. 
Table 4. Effect of four organic fertilizers alone and combined with bio-agents on cowpea forage yield parameters under field conditions infected with root-knot nematodes, Meloidogyne spp., during seasons 2016-2017

\begin{tabular}{|c|c|c|c|c|c|c|}
\hline \multirow[b]{2}{*}{ Treatment } & \multicolumn{3}{|c|}{ Summer season, 2016} & \multicolumn{3}{|c|}{ Summer season, 2017} \\
\hline & 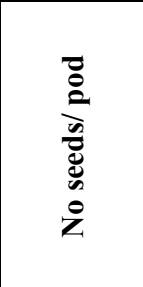 & 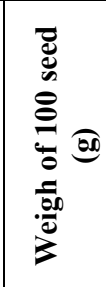 & 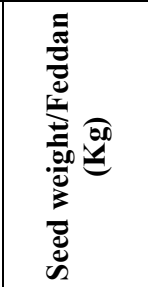 & 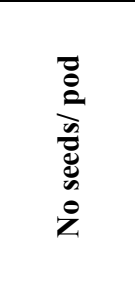 & 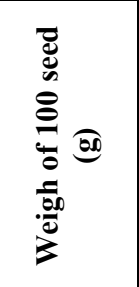 & 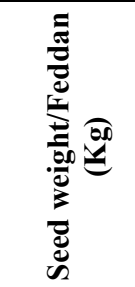 \\
\hline B. megaterium & $10.30 \mathrm{abc}$ & $8.55 \mathrm{ab}$ & $777.45 \mathrm{de}$ & $9.52 \mathrm{~cd}$ & $9.59 \mathrm{ab}$ & $791.50 \mathrm{~h}$ \\
\hline T. viride & $9.80 \mathrm{bcd}$ & $8.97 \mathrm{a}$ & $732.70 \mathrm{ef}$ & $8.47 \mathrm{de}$ & $9.25 \mathrm{abc}$ & $728.50 \mathrm{j}$ \\
\hline Farmyard manure (A) & $9.80 \mathrm{bcd}$ & $8.73 \mathrm{a}$ & $617.64 \mathrm{fg}$ & $12.52 \mathrm{ab}$ & $9.85 \mathrm{ab}$ & $605.77 \mathrm{k}$ \\
\hline Chicken manure (B) & $11.83 \mathrm{a}$ & $9.2 \mathrm{a}$ & $775.42 \mathrm{de}$ & $10.69 \mathrm{bcd}$ & $10.52 \mathrm{a}$ & $717.30 \mathrm{j}$ \\
\hline Date palm compost $(C)$ & $10.17 \mathrm{abcd}$ & $8.31 \mathrm{ab}$ & $793.42 \mathrm{de}$ & $12.58 \mathrm{ab}$ & $9.02 \mathrm{abcd}$ & $733.95 \mathrm{j}$ \\
\hline Filter cake mud (D) & $8.70 \mathrm{~cd}$ & $8.69 \mathrm{a}$ & $790.37 \mathrm{de}$ & $9.45 \mathrm{~cd}$ & $9.09 \mathrm{abcd}$ & $816.55 \mathrm{~g}$ \\
\hline B. megaterium $+\mathbf{A}$ & $11.57 \mathrm{ab}$ & $9.43 \mathrm{a}$ & $741.30 \mathrm{def}$ & $13.26 \mathrm{a}$ & $10.03 \mathrm{ab}$ & $769.10 \mathrm{i}$ \\
\hline B. megaterium $+\mathrm{B}$ & 8.37 cde & $7.94 \mathrm{ab}$ & $972.26 \mathrm{bc}$ & $8.47 \mathrm{~d} \mathrm{e}$ & 7.56 cde & $1011.53 \mathrm{c}$ \\
\hline B. megaterium $+\mathrm{C}$ & $10.17 \mathrm{abcd}$ & $8.87 \mathrm{a}$ & $944.20 \mathrm{bc}$ & $11.02 \mathrm{abc}$ & $9.42 \mathrm{ab}$ & $960.90 \mathrm{~d}$ \\
\hline B. megaterium $+\mathrm{D}$ & $8.57 \mathrm{cde}$ & $7.94 \mathrm{ab}$ & $876.08 \mathrm{~cd}$ & $8.96 \mathrm{~cd}$ & $7.36 \mathrm{de}$ & $955.16 \mathrm{~d}$ \\
\hline T. viride $+\mathbf{A}$ & $9.50 \mathrm{~cd}$ & $9.29 \mathrm{a}$ & $876.58 \mathrm{~cd}$ & $10.02 \mathrm{~cd}$ & $10.52 \mathrm{a}$ & $917.45 \mathrm{e}$ \\
\hline T. viride $+\mathrm{B}$ & $9.87 \mathrm{bcd}$ & $8.36 \mathrm{ab}$ & $1027.28 \mathrm{~b}$ & $10.05 \mathrm{~cd}$ & $8.96 \mathrm{abcd}$ & $1144.30 \mathrm{~b}$ \\
\hline T. viride $+C$ & $8.27 \mathrm{de}$ & $8.03 \mathrm{ab}$ & $1228.40 \mathrm{a}$ & $9.42 \mathrm{gd}$ & $8.25 \mathrm{bcd}$ & $1211.45 \mathrm{a}$ \\
\hline T. viride $+D$ & $9.10 \mathrm{~cd}$ & $7.61 \mathrm{ab}$ & $844.24 \mathrm{cde}$ & $10.25 \mathrm{bcd}$ & $7.36 \mathrm{de}$ & $872.69 \mathrm{f}$ \\
\hline Control & $6.69 \mathrm{e}$ & $6.25 \mathrm{~b}$ & $535.50 \mathrm{~g}$ & $6.26 \mathrm{e}$ & $6.25 \mathrm{e}$ & 539.501 \\
\hline
\end{tabular}

Different letters indicate significant differences among treatments within the same column according to least significant difference test $(\mathrm{P} \leq 0.05)$.

The effect of four organic fertilizers and two bio-agents on the content of plant elements and protein in cowpea forage (Balady) plants infected with root-knot nematodes, Meloidogyne spp., under field conditions:

Table 5 results showed that there were differences among treatments in the content of elements and protein in cowpea forage. Nitrogen content of cowpea forage was the highest when $B$. megaterium was applied with filter cake mud $(4.62 \%)$, date palm compost $(4.51 \%)$, or chicken manure $(4.48 \%)$, compared with control treatment $(3.12 \%)$. While, the potassium content of cowpea forage was significantly higher than all treatments when combined $B$. megaterium with chicken manure was (2.96), and T.viride was (2.92). The combined treatment of chicken 
manure with $B$. megaterium gave a high content of phosphorus was (0.28), followed by treatments chicken manure individually or in combined with $T$. viride, as well as combined treatment of $B$. megaterium with farmyard manure gave the same result (0.26). As for the total protein content, the most effective treatments increased the total protein were combination of B. megaterium with filter cake mud (28.88), followed by $B$. megaterium with date palm compost (28.19).

Table 5. Effect of four organic fertilizers, and two bio-agents on cowpea forage elements and protein content infected with root-knot nematodes, Meloidogyne spp., under field conditions

\begin{tabular}{|c|c|c|c|c|}
\hline Treatment & N\% & K\% & $\mathbf{P \%}$ & Protein \% \\
\hline B. megaterium & $4.00 \mathrm{abcd}$ & $2.22 \mathrm{def}$ & $0.23 \mathrm{bcd}$ & 25.00 bcde \\
\hline$T$. viride & $3.36 \mathrm{de}$ & $2.01 \mathrm{efg}$ & 0.22 bcde & $21.00 \mathrm{f}$ \\
\hline Farmyard manure (A) & 3.52 cde & $2.56 \mathrm{bc}$ & $0.23 \mathrm{bcd}$ & $22.00 \mathrm{ef}$ \\
\hline Chicken manure (B) & 3.98 abcd & $2.26 \mathrm{cde}$ & $0.26 \mathrm{ab}$ & 24.88 cde \\
\hline Date palm compost(C) & $3.88 \mathrm{bcd}$ & $1.97 \mathrm{efg}$ & 0.22 bcde & $24.25 \mathrm{de}$ \\
\hline Filter cake mud(D) & $3.32 \mathrm{de}$ & $1.80 \mathrm{~g}$ & $0.19 \mathrm{de}$ & $20.75 \mathrm{f}$ \\
\hline B. megaterium $+\mathbf{A}$ & $4.36 \mathrm{ab}$ & $2.56 \mathrm{bc}$ & $0.26 \mathrm{ab}$ & $27.25 \mathrm{abcd}$ \\
\hline B. megaterium $+\mathrm{B}$ & $4.48 \mathrm{ab}$ & $2.96 \mathrm{a}$ & $0.28 \mathrm{a}$ & $28.00 \mathrm{abc}$ \\
\hline B. megaterium $+\mathrm{C}$ & $4.51 \mathrm{ab}$ & $2.44 \mathrm{bcd}$ & $0.25 \mathrm{abc}$ & $28.19 \mathrm{ab}$ \\
\hline B. megaterium $+\mathrm{D}$ & $4.62 \mathrm{a}$ & $2.39 \mathrm{bcd}$ & 0.22 bcde & $28.88 \mathrm{a}$ \\
\hline$T$. viride $+\mathrm{A}$ & $3.92 \mathrm{abcd}$ & $2.64 \mathrm{ab}$ & $0.24 \mathrm{abc}$ & $24.50 \mathrm{de}$ \\
\hline T. viride $+\mathrm{B}$ & $4.19 \mathrm{abc}$ & $2.92 \mathrm{a}$ & $0.26 \mathrm{ab}$ & $26.19 \mathrm{abcd}$ \\
\hline T. viride $+C$ & $4.08 \mathrm{abc}$ & $2.29 \mathrm{cde}$ & $0.23 \mathrm{bcd}$ & $25.50 \mathrm{bcd}$ \\
\hline T. viride $+D$ & 3.96 abcd & $1.92 \mathrm{fg}$ & 0.21 cde & $24.75 \mathrm{de}$ \\
\hline Control & $3.12 \mathrm{e}$ & $1.09 \mathrm{~h}$ & $0.18 \mathrm{e}$ & $19.50 \mathrm{f}$ \\
\hline
\end{tabular}

Different letters indicate significant differences among treatments within the same column according to least significant difference test $(\mathrm{P} \leq 0.05)$.

Effect of four organic fertilizers, and two bio-agents on the activity of oxidative enzymes on the cowpea forage (Balady) infected with $M$. incognita under greenhouse conditions:

The effect of organic fertilizers and bio-agents on the activities of defense-related enzymes viz., PO, PPO, PAL, $\beta$ - $(1,3)$-glucanase ,and chitinase on cowpea forage (Balady) infected with $M$. incognita under greenhouse conditions was studied alone and in combination with $B$. megaterium and $T$. viride as an inducer resistance. Data in Figures (1-5) showed that all treatments generally increased activities of defenserelated enzymes compared to control treatment. The combination between organic fertilizers and bio-agents increased activities of defense-related enzymes more than used any of them, individually. Data in Fig. 1 showed that the treatments ( $T$. viride with chicken manure, and $T$. viride with date palm compost) increased the activity level of peroxides enzyme with (1.302), and (1.292) compared with control treatment (0.526). The increase in enzyme poly phenoloxidase activity in Fig. 2 has been resulted by combing treatments of chicken manure with bio-agents, $T$. viride with (1.299) and B. megaterium with (1.28) compared with control treatment (0.686). Also, in Fig. 3 the results indicated that combined treatments of chicken manure 
with bio-agents increased the activity level of the enzyme of phenylalanine ammonia lyase compared with control treatment and recorded the highest value of the treatments with, B. megaterium while, it was (1.899) with $T$. viride.

A results of combined $T$. viride treatment with all organic fertilizers resulted in the highest levels of activity in each of pathogenesis related protein $\beta$ - $(1,3)$-glucanase and chitinase enzymes in Fig. 4, as well as, Fig. 5, compared with other treatments and control treatment.

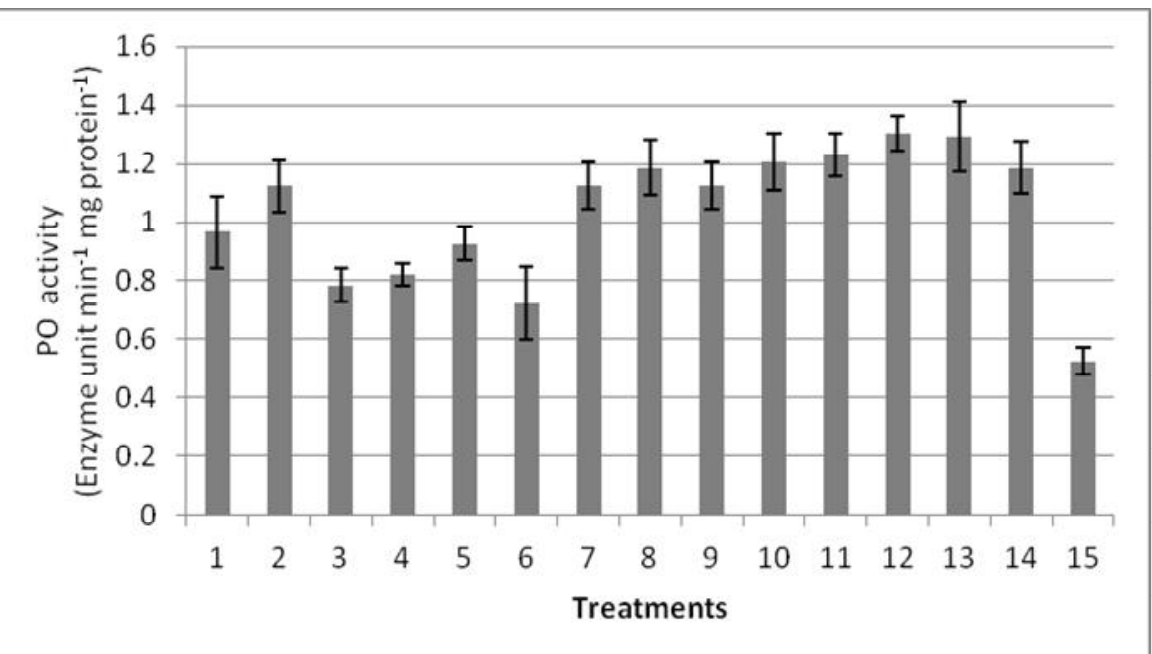

Fig. 1. The effect of organic fertilizers treatments and bio-agents on the activity of peroxidase enzyme (enzyme unit $\mathrm{mg}$ protein/min) alone and in combination with bio-agents (1-B. megaterium, 2- $T$. viride, 3Farmyard manure (A), 4- Chicken manure (B), 5- Date palm compost (C), 6- Filter cake mud (D), 7- B. megaterium + A, 8- B. megaterium $+B$, 9- B. megaterium $+\mathrm{C}$, 10- B. megaterium $+\mathrm{D}$, 11- T. viride $+\mathrm{A}, 12-\mathrm{T}$. viride $+\mathrm{B}, 13-T$. viride $+\mathrm{C}, 14-T$. viride $+\mathrm{D}$, and 15- Control). 


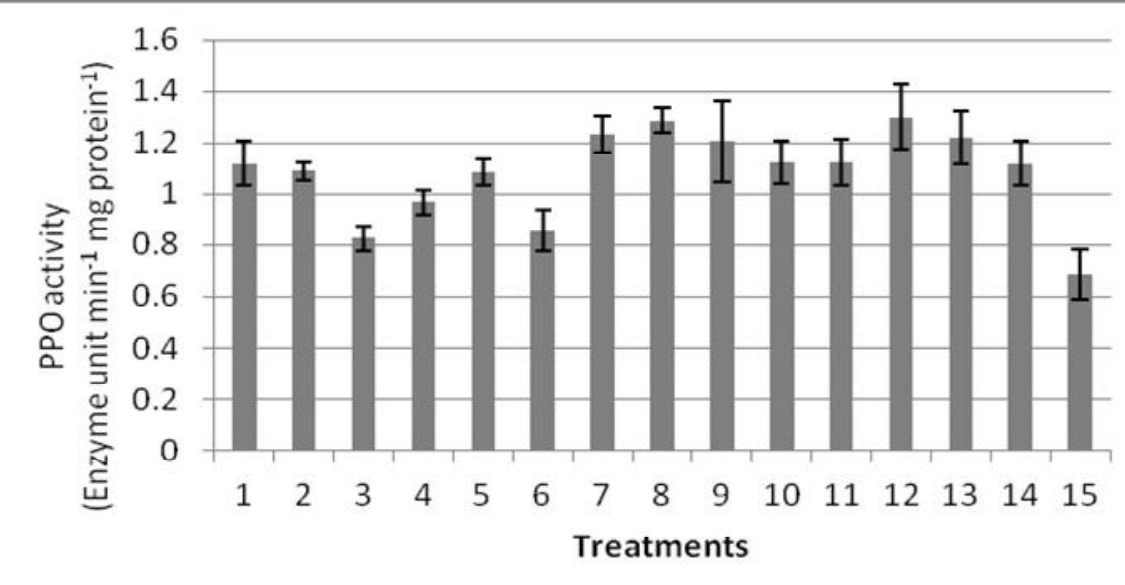

Fig.2. The effect of organic fertilizers treatments and bio-agents on the activity of poly phenol oxidase enzyme (enzyme unit $\mathrm{mg}$ protein/min) alone and in combination with bio-agents (1-B. megaterium, 2- $T$. viride, 3Farmyard manure (A), 4- Chicken manure (B), 5- Date palm compost (C), 6- Filter cake mud (D), 7- B. megaterium +A, 8- B. megaterium +B , 9- B. megaterium $+\mathrm{C}, 10-B$. megaterium $+\mathrm{D}$, 11- T. viride $+\mathrm{A}, 12-T$. viride $+\mathrm{B}$, 13- T. viride $+\mathrm{C}, 14-T$. viride $+\mathrm{D}$, and 15- Control).

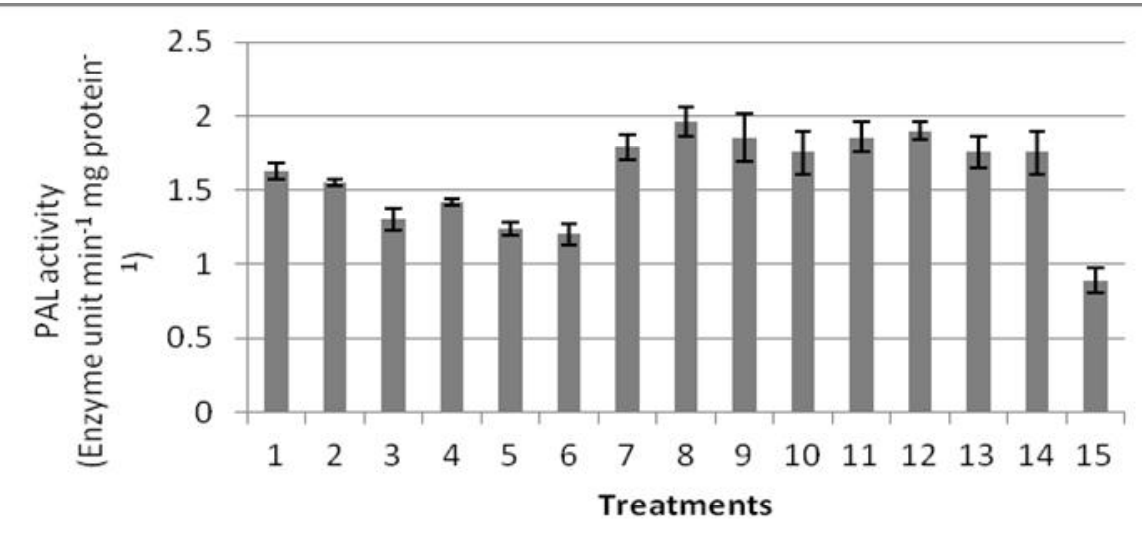

Fig.3. The effect of organic fertilizers treatments and bio-agents on the activity of phenylalanine ammonia lyase enzyme (enzyme unit $\mathrm{mg}$ protein/min) alone and in combination with bio-agents (1-B. megaterium, 2- $T$. viride, 3- Farmyard manure (A), 4- Chicken manure (B), 5- Date palm compost (C), 6- Filter cake mud (D), 7- B. megaterium + A, 8B. megaterium $+\mathrm{B}$, 9- B. megaterium $+\mathrm{C}, 10-B$. megaterium $+\mathrm{D}$, 11- T. viride $+\mathrm{A}$, 12- T. viride $+\mathrm{B}, 13-\mathrm{T}$. viride $+\mathrm{C}, 14-\mathrm{T}$. viride $+\mathrm{D}$, and 15- Control). 


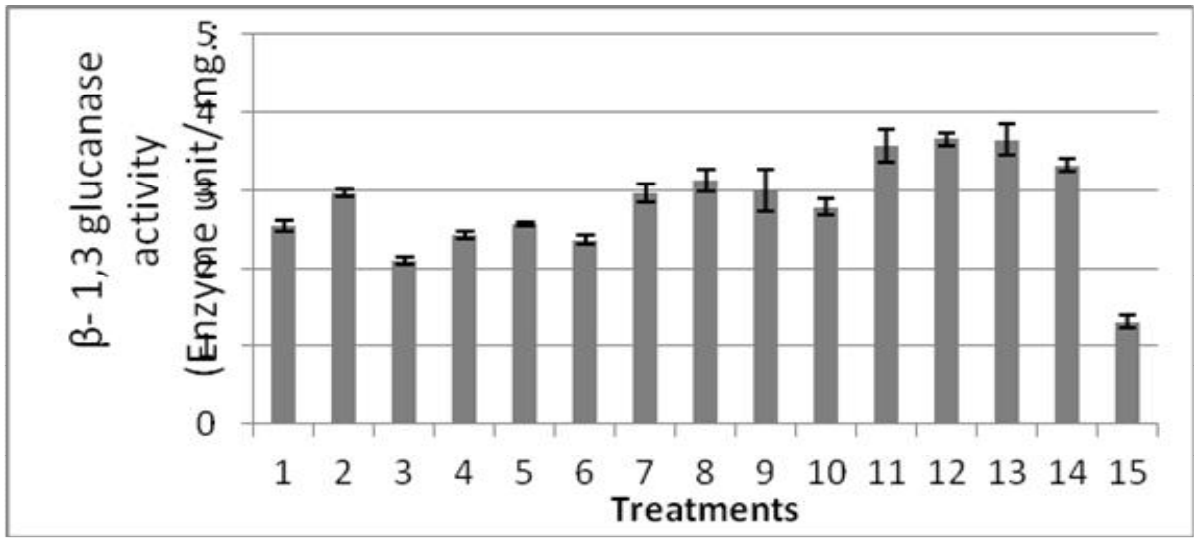

Fig. 4. The effect of organic fertilizers treatments and bio-agents on the activity of $\beta$ - $(1,3)$ glucanase enzyme (enzyme unit $\mathrm{mg}$ protein/min) alone and in combination with bio-agents (1-B. megaterium, $2-T$. viride, 3- Farmyard manure (A), 4- Chicken manure (B), 5- Date palm compost (C), 6- Filter cake mud (D), 7- B. megaterium +A, 8- B. megaterium $+\mathrm{B}$, 9- B. megaterium $+\mathrm{C}, 10-B$. megaterium $+\mathrm{D}, 11-\mathrm{T}$. viride $+\mathrm{A}, 12-\mathrm{T}$. viride $+\mathrm{B}, 13-\mathrm{T}$. viride $+\mathrm{C}, 14-\mathrm{T}$. viride $+\mathrm{D}$, and 15Control).

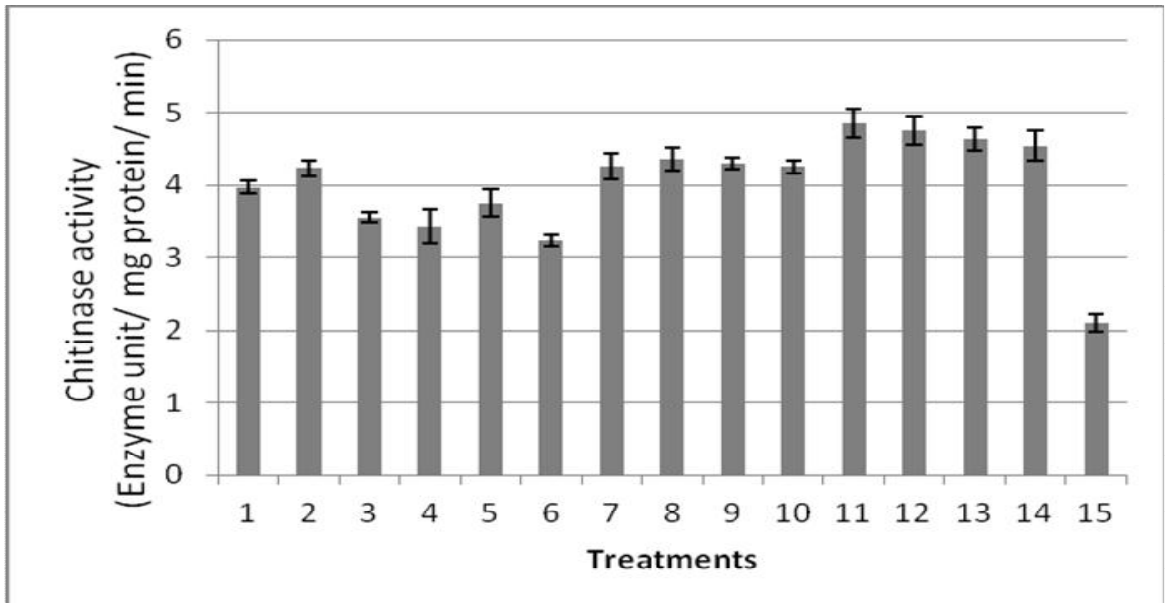

Fig.5. The effect of organic fertilizers and bio-agents treatments on the activity of chitinase enzyme (enzyme unit $\mathrm{mg}$ protein/min) alone and in combination with bio-agents (1-B. megaterium, 2- T. viride, 3Farmyard manure (A), 4- Chicken manure (B), 5- Date palm compost (C), 6- Filter cake mud (D), 7- B. megaterium +A, 8- B. megaterium $+\mathrm{B}, 9-\mathrm{B}$. megaterium $+\mathrm{C}, 10-\mathrm{B}$. megaterium $+\mathrm{D}, 11-\mathrm{T}$. viride $+\mathrm{A}, 12-$ T. viride $+\mathrm{B}, 13-T$. viride $+\mathrm{C}$, 14- T. viride $+\mathrm{D}$, and 15- Control). 
Effect of organic fertilizers and bio-agents on total phenol compounds (TPC):

Data in Fig. 6 indicated that all treatments increase total phenol contents in cowpea forage plants compared with untreated plant (control) either applied to individually or in combination. The combination between organic fertilizers and bioagents recorded higher contents of TPC in cowpea forage plants more than when applied them individually. The combination between $T$. viride with farmyard manure and $T$. viride with chicken manure gave the highest contents of TPC in cowpea forage plants compared with untreated plants as (control).

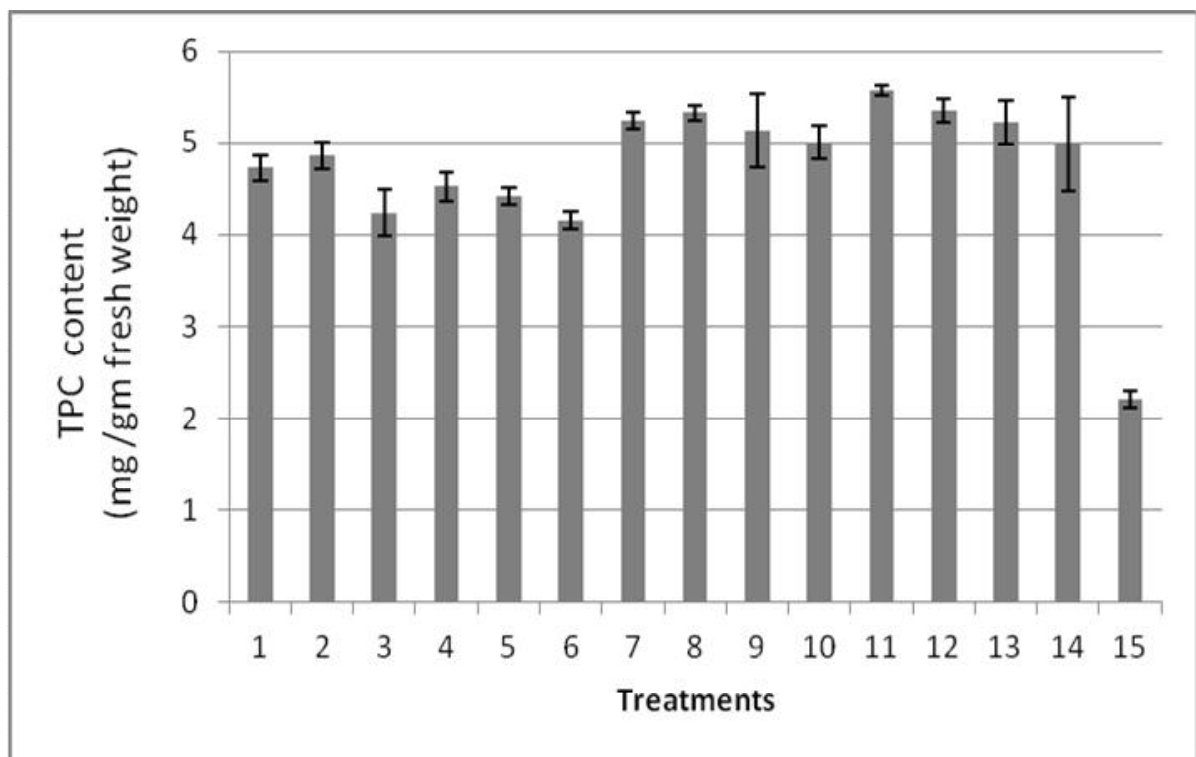

Fig. 6. Effect of organic fertilizers and bio-agents individually and in combination on total phenol compounds (1-B. megaterium, 2- T. viride, 3- Farmyard manure (A), 4- Chicken manure (B), 5- Date palm compost (C), 6- Filter cake mud (D), 7- B. megaterium +A, 8- B. megaterium $+\mathrm{B}$, 9- B. megaterium $+\mathrm{C}, 10-\mathrm{B}$. megaterium $+\mathrm{D}, 11-\mathrm{T}$. viride $+\mathrm{A}$, 12- T. viride $+\mathrm{B}, 13-T$. viride $+\mathrm{C}, 14-T$. viride $+\mathrm{D}$, and 15Control).

\section{Dis c us sion}

Microorganisms that can grow in the rhizosphere are the front line defense against pathogen attack roots and are ideal for use as bio-control agents. Biological control of soilborne plant pathogens with rhizobacteria have been studied as an alternative to chemical control (Weller, 1988). Some bacteria that live in direct contact with roots at different microsites offered by mucigel, epidermis or cortex, or may even penetrate intercellular spaces so that the metabolites of their production can easily act on root cells. 
Results obtained from applying treatments under field conditions indicated that, all tested treatments significantly reduced nematode infection compared with control treatment. The combined treatment $B$. megaterium with chicken manure gave the highest reduction in second stage juveniles $\left(\mathrm{j}_{2}\right)$ of Meloidogyne spp., in soil. These results are in agreement with (Tong-Jian et al., 2013) since they reported that applied of Bacillus cereus with bio-organic fertilizer, chicken manure was more effective in control M.incognita in tomato. Biological control agents of the soil borne plant pathogens often applied to soils combined with organic materials (Mittal et al., 1995). Organic materials contribute to enhanced biological activity against the target pathogen by providing the necessary nutrients for the initial growth of biocontrol agents in the soil. The breakdown of an organic material may release toxic substances and nematicides that contribute to nematode control (Esnard et al., 1998). In the present study, combined treatment of $T$. viride with date palm compost reduced each of numbers of root galls, and number of egg-masses per plant. The tested study was supported by (Olabiyi et al., 2016) they reported that application of neem composts and $T$. harzianum significantly reduced the final nematode population of root-knot nematode in cowpea varieties under field conditions. This may be attributed to the direct parasitism of fungi as bio-control agents that are one of the main mechanisms responsible for the plant-parasitic nematode control (Dababat and Sikora, 2007). Many investigators reported that Trichoderma spp., have been used as a bio-control agent against plant-parasitic nematodes, and that fungus can also promote plant and have the ability to colonize the root surface and the cortex (Sharon et al., 2001). T. viride in combination with the organic amendment was also known to produce growth hormones, which have been observed to have added responsive in stimulating the plant vigor. The fungus Trichoderma has been reported to be produced not only for parasitic nematode and inactive pathogen enzymes, but also to help intolerance to stress conditions through increased root development.

In the current study the application of bio-agents $T$. viride, and B. megaterium with organic fertilizers date palm compost or chicken manure increased plant growth parameters viz., plant height, number of branches per plant, and fresh weight compared to control treatment in the two successive seasons. (Siddiqui et al., 2007) they reported that inoculation of any plant growth promoting rhizobacteria (PGPR) species alone or together with Rhizobium increased plant growth by $M$. javanica inoculated on lentil plants. Also, (Mahdy 2002) demonstrated that all plants treated with Bacillus cereus S18 combined with $M$. incognita, gave improvement of plant growth, compared with the untreated tomato plants. Enhancing plant development is might be the microbial metabolites of the rhizobacteria under research having a double impact; indirectly by suppressing nematode reproduction resulting in relief of negative effects on plant growth or directly include the production of phytohormones, promotion through the enhanced availability of nutrients, reduction of ethylene levels, production of antibiotics and induced systemic resistance (Holland, 1997).

Obtained data from the present study proved that all tested treatments significantly increased the content of $\mathrm{N}, \mathrm{P}, \mathrm{K}$, and protein in cowpea forage 
compared with control treatments. The application of treatments (B. megaterium) alone and combined with other organic fertilizers increased all of $\mathrm{N}, \mathrm{P}, \mathrm{K}$ and protein content in plants. These results are in agreement with (Radhakrishnan and Lee, 2016) when they reported that $B$. megaterium has the ability to increase the solubility of the phosphorous in soil and increase their transport to the maize roots. In addition that, enhancement of plant endogenous proteins, amino acids, sugars, photosynthetic pigments and minerals $(\mathrm{K}, \mathrm{Mg}, \mathrm{Na}, \mathrm{P}, \mathrm{Fe}, \mathrm{Zn}$, and $\mathrm{N}$ ) recorded. Also, the beneficial effect of Bacillus spp., convert the complex form of an essential nutrients, such as $\mathrm{P}$ and $\mathrm{N}$, to a simple available form that is used during uptake by oriental melon roots (Kang et al., 2015).

In the second part of this study, the results showed that all treatments increased the activities of oxidative enzymes (peroxidase, polyphenol oxidase, phenylalanine ammonia lyase, pathogenesis related protein (chitinase and $\beta 1,3$ gluconase) but, combined treatments of bio-agents $B$. megaterium and $T$. viride with organic fertilizers increased the levels of an oxidative enzymes than individual treatments under greenhouse conditions. The combinations of ( $T$. viride with chicken manure, and $T$. viride with date palm compost) increased the activity level of peroxides enzyme. While, the combined treatments of $B$. megaterium and $T$. viride with chicken manure increased the levels, of poly phenoloxidase and phenylalanine ammonia lyase enzyme activity.

It may seem to, that the role of oxidative enzymes can be explained as oxidation of phenols to oxidized products (quinons), which limit pathogenic activity. The reduction in disease severity was associated with an increase in enzyme activity (peroxides, polyphenoloxidase, chitinous and catalase) in plant pre-treated with biotic and abiotic inducers. Many investigators have demonstrated the ability of various PGPRs for plant protection to induce systemic resistance against various pests and diseases (Lawton and Lamb, 1987). In addition, peroxidase plays a role in the removal of hydrogen peroxide toxic effects from tissues in plant defense systems and in the synthesis of intermolecular bonding, fortifying cell walls at pathogen invasion (Passardi et al., 2004).

\section{$R$ e f e r e n e s}

Adegbite, A.A. 2011. Assessment of yield loss of cowpea (Vigna unguiculata L.) due to root-knot nematode, Meloidogyne incognita under field conditions. American. J. of experimental Agri,1(3):79-85.

Agyarko, K. and Asante, J.S. 2005. Nematode dynamics in soil amended with neem leaves and Poultry manure. Asian J. Plant Sci, 4 (4):426-428.

Anonymous, 1991. A Software Program for the MSTAT-C Design, Management and Analysis of Agronomic Research Experiments. Michigan State University.

Anonymous, 1995. Official methods of analysis $16^{\text {th }}$ edition. Association of Official Analytical Chemists, Washington, D.C., USA. 
Barker, K.R.; Carter, C.C. and Sasser, J.N. 1985. An advanced treatise on Meloidogyne. Vol. 2: Methodology. Acooperative Publication of the Department of Plant Pathology and the United States Agency for International Development. North Carolina State University.

Biles, C. L. and Martyn, R. D. 1993. Peroxidase, polyphenoloxidase, and shikimate dehydrogenase isozymes in relation to tissue type, maturity and pathogen induction of watermelon seedlings. Plant Physiol. Biochem. 31:499-506.

Bradford, M.M. 1976. Rapid and sensitive method for quantitation of microgram quantities of protein utilising principle of protein dye binding. Analyt. Biochem. 72: 248-254.

Cavalcanti, F.R ; Lima, J.P. ; Ferreira-Silva, S.L. ; Viégas, R.A.and Silveira, J.A. 2007. Roots and leaves display contrasting oxidative response during salt stress and recovery in cowpea. J. Plant Physiol, 164: 591-600.

Dababat, A.F.A.A. and Sikora, R. A. 2007. Use of Trichoderma harzianum and Trichoderma viride for the biological control of Meloidogyne incognita on Tomato. Jordan J. Agric. Sci, 3: 297-308.

Daykin, M. E. and Hussy, R. S. 1985. Staining and histopathological techniques in nematology. In: An Advanced Treatise on Meloidogyne. Biology and Control. K. R. Barker, C. C. Carter, and J. N. Sasser, eds. North Carolina State University, Raleigh, Vol. 1., pp19-35.

Esnard, J.; Marban-Mendoza, N. and Zuckerman, B.M. 1998. Effects of three microbial broth cultures and an organic amendment on growth and populations of free living and plant-parasitic nematodes on banana. European Journal of Plant Pathology, 104 (5):457-463.

Evenhuis, B. and Dewaard, P.W. 1980. Principles and practices in plant analysis. F.A.O. Soil Bull. 39(1):152-163.

Fernandez, C.; Rodriguez-Kabana, R .; Warrior, P. and Kloepper, J. W. 2001. Induced soil suppressiveness to a root-knot nematode species by a nematicide. Biol. Control, 22 (2): 103-114.

Gauillard, F.; Richardforget, F. and Nicolas, J. 1993. New spectrophotometric assay for polyphenol oxidase activity. Analytical Biochemistry, 215(1):59-65.

Gomez, K.A. and Gomez, A.A. 1984. Statistical Procedures for Agricultural Research. Wiley-interscience Publication.New York,680p.

Gowen, S.R. and Ahmad, R. 1990. Pasteuria penetrans for control of pathogenic nematodes. Aspects of Applied Biology, 24: 25-32.

Hamd Alla, W.A.; Shalaby, E.M..; Dawood, R.A. and Zohry, A.A. 2014. Effect of cowpea (Vigna sinensis L.) with maize (Zea mays L.) intercropping on yield and its components. International Journal of Biological, Food, Veterinary and Agricultural Engineering, 8(11): 1200-1206. 
Hammerschmidt, R .; Nuckles, E.M. and Kuć, J. 1982. Association of enhanced peroxidase activity with induced systemic resistance of cucumber to Colletotrichum lagenarium. Physiological Plant Pathology, 20(1):73-82.

Holland, M.A. 1997. CAM's razor applied to hormonology: Are cytokinnins produced by plants. Plant Physiology, 115:865-868.

Hussey, R.S. and Barker, K.R. 1973. Comparison of methods for collecting inocula of Meloidogyne spp., including a new technique. Plant Disease Reporter. 57:1025-1028.

Iheukwumere, C.C.; Atiri, G.I.; Fawole, B.and Dashiell, K.E. 1995. Evaluation of some commonly grown soybean cultivars for resistance to root-knot nematodes and soybean mosaic virus in Nigeria. Fitopatol Bras., 20: 190-193.

Iqbal, M.A. 2015. Improving germination and seedling vigour of cowpea (Vigna unguiculata L.) with different priming techniques. Am-Eur J Agric Environ Sci, 15:265-270.

Jansson, H.B.; Jeyaprakash, A. and Zuckerman, B.M. 1985. Control of root-knot nematodes on tomato by the endoparasitic fungus Meria coniospora. Journal of Nematology, 17(3):327.

Kang, S.M.; Radhakrishnan, R.; Lee, K.E.; You, Y.H.; Ko, J.H.; Kim, J.H. and Lee, I.J. 2015. Mechanism of plant growth promotion elicited by Bacillus sp.LKE15 in oriental melon. Acta Agriculturae Scandinavica, Section B-Soil \& Plant Science, 65(7):637-647.

Lawton, M.A. and Lamb, C.J. 1987. Transcriptional activation of plant defense genes by fungal elicitor, wounding, and infection. Molecular and Cellular Biology, 7(1):335-341.

Mahdy, M.E. 2002. Biological control of plant parasitic nematodes with antagonistic bacteria on different host plants. Ph.D. thesis,.Hohen Landwirtschaftlichen Fakultät der Rheinischen Friedrich-Wilhelms-Universitätzu Bonn,171p.

Mittal, N.; Saxena, G. and Mukerji, K.G. 1995. Integrated control of root-knot disease in three crop plants using chitin and Paecilomyces lilacinus. Crop Protection, 14(8): 647-651.

Murphy, J. and Riley, J.P. 1962. A modified single solution method for the determination of phosphorus in natural waters: Analytica Chimica Acta, 27: 3136 .

Oka, Y.; Nacar, S.; Putieusky, E.; Ravid, U.; Zohara, Y.and Spiegal, Y. 2000. Nematicidal activity of essential oils and their components against the root knot nematode. Phytopathol., 90: 710-715.

Olabiyi, T.I.; Ojo, O.J. and Adewuyi, B.O. 2016. Impact assessment of neem compost and Trichoderma harzianum solution in the control of root knot nematode disease on cowpea. International Journal of Phytopathology, 5(2), $67-71$. 
Oostenbrink, M. 1966. Major characteristics of the relation between nematodes and plants. Mededelingen Landbouwhogeschool Wageningen 66:1-46.

Olowe, T. 2009. Cowpea Germplasm Resistant to Meloidogyne arenaria Race 1, Meloidogyne incognita Race 4 and Meloidogyne javanica. European Journal of Scientific Research 28(3): 338-350.

Pan, S.Q.; Ye, X.S. and Kuć, J. 1991. Association of $\beta$-1, 3-glucanase activity and isoform pattern with systemic resistance to blue mould in tobacco induced by stem injection with Peronospora tabacina or leaf inoculation with tobacco mosaic virus. Physiological and Molecular Plant Pathology, 39 (1):25-39.

Passardi, F.; Penel, C. and Dunand, C. 2004. Performing the paradoxical: How plant peroxidases modify the cell wall. Trends in Plant Science, (9):534-40.

Radhakrishnan, R. and Lee, I.J. 2016. Gibberellins producing Bacillus methylotrophicus KE2 supports plant growth and enhances nutritional metabolites and food values of lettuce. Plant Physiology and Biochemistry, 109:181-189.

Saikia, R.; Yadav, M.; Varghese, S.; Singh, B.P.; Gogoi, D.K.; Kumar, R. and Arora, D.K. 2006. Role of riboflavin in induced resistance against Fusarium wilt and charcoal rot diseases of chickpea. Plant Pathol. J., 22 (4): 339-347.

Sharon, E.; Bar-Eyal, M.; Chet, I.; Herrera-Estrella, A.; Kleifeld, O.and Spiegel, Y. 2001. Biological control of the root-knot nematode Meloidogyne javanica by Trichoderma harzianum. Phytopathology, 91:687-693.

Siddiqui, I.A.; Ehetshamul-Haque, S.and Shaukat, S.S. 2001.Use of rhizobacteria in the control of root rot-root knot disease complex of mungbean. J. Phytopathol. 149:337-346.

Siddiqui, Z.A.and Mahmood, I. 1995. Management of Meloidogyne incognita race 3 and Macrophomina phaseolina by fungus culture filtrates and Bacillus subtilis on chickpea. Fundamental Applied Nematology 18: 71-76.

Siddiqui, Z.A.; Baghel, G. and Akhtar, M.S. 2007. Bio-control of Meloidogyne javanica by Rhizobium and plant growth-promoting rhizobacteria on lentil. World J Microbiol Biotechnol, 23: 435-441.

Singh, B. B.; Ehlers, J. D.; Sharma, B.and Freire Filho F. R . 2002. "Recent progress in cowpea breeding,"I n Challenges and Opportunities for Enhancing Sustainable Cowpea Production eds Fatokun C.A.Tarawali S.S., Singh B.B., Kormawa P.M., Tamò M., eds. (Ibadan: IITA; ), pp 22-40.

Taylor, A.L. and Sasser, J.N. 1978. Identification and Control of Root-knot nematodes (Meloidogyne spp) Crop. Publ. Dept. Plant Pathol., North Carolina Stat Univ. US Agency Int. Dev. Raleigh N.C. 111 p.

Tong-Jian, X.I.A.O.; Fang, C.H.E.N.; Chao, G.A.O.; Qing-Yun, Z.H.A.O.; Qi-Rong, S.H.E.N. and Wei, R.A.N. 2013. Bacillus cereus X5 enhanced bio-organic 
fertilizers effectively control root-knot nematodes (Meloidogyne sp.). Pedosphere, 23(2):160-168.

Weller, D.M. 1988. Biological control of soil borne plant pathogens in the rhizosphere with bacteria. Annual Reviews in Phytopathology 26: 379-407.

Wirth, S.J.and Wolf, G.A. 1992. Micro-plate colourimetric assay for endo-acting cellulse, xylanase, chitinase, 1,3-beta-glucanase and amylase extracted from forest soil horizons. Soil Biol. Biochem. 24:511-519.

Received 01/03/2018

in revised form 02/04/2018) 
فاعلية بعض الأسمدة العضوية وعوامل المكافحة الحيوية

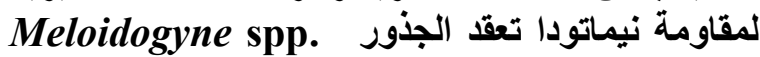

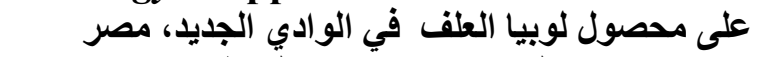

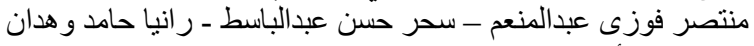
معهد بحوث أمر اض النباتاتـ مركز البحوث الزر اعية- الجيزة - مصر.

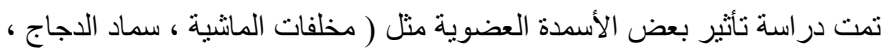

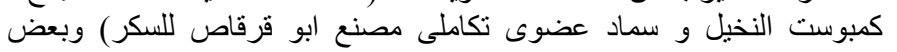

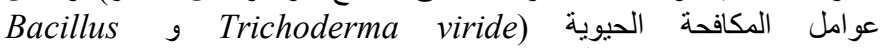
بمفردها أو مشتركة مع بعضها البعض في مقاو مة نيماتودا تعقد

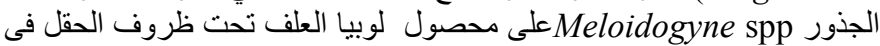

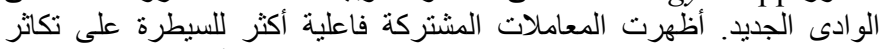

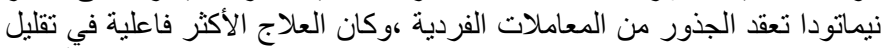

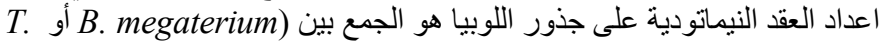
(viride

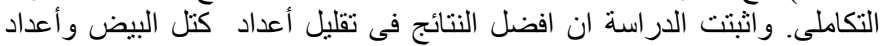

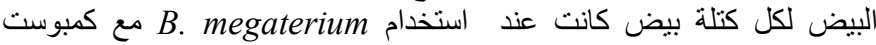

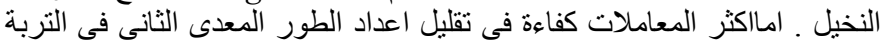

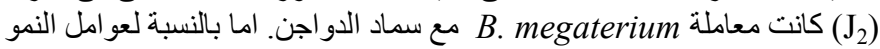

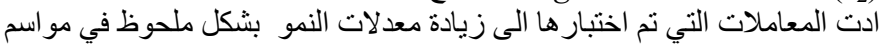

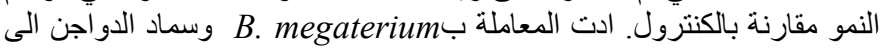

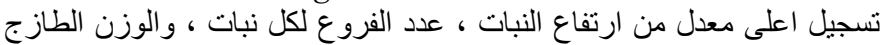

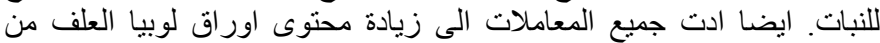

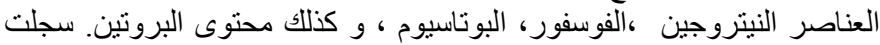

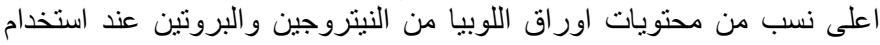

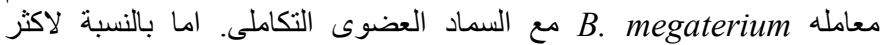

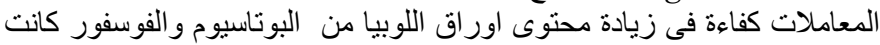

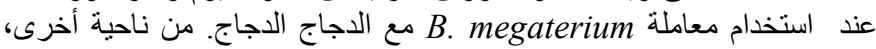

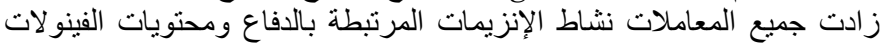

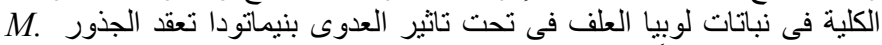

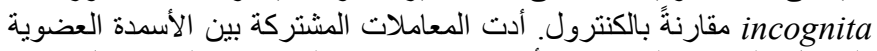

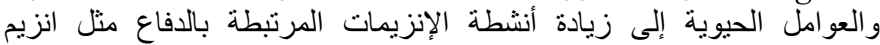

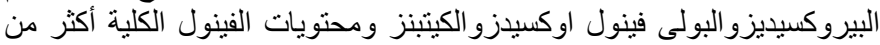
تطبيقها بشكل فردي. 